\title{
FAKTOR MAKROEKONOMI YANG MEMPENGARUHI PERGERAKAN HARGA SAHAM PADA INDEKS SAHAM SYARIAH INDONESIA (ISSI) DI BURSA EFEK INDONESIA (BEI) 1)
}

\author{
Martien Rachmawati \\ Mahasiswa Program Studi Ekonomi Islam-Fakultas Ekonomi dan Bisnis-Universitas Airlangga \\ Email:martien_rachma@yahoo.com
}

Nisful Laila

Departemen Ekonomi Syariah-Fakultas Ekonomi dan Bisnis-Universitas Airlangga

Email: nisful.laila@gmail.com

\begin{abstract}
:
The capital market presence is such an important concern for many country because it relate to its function as economic booster through investation. This study aims to analyze macro economic factors that can affect the movement of stock price at Indonesia Sharia Stock Index in Indonesia Stock Exchange as the inflation factor, SBI interest rates and exchange rates. The method used in this research is quantitative approaches in which data is obtained from Indonesia Stock Exchange and Bank of Indonesia. The data used is the time series data starting from January 2012 to April 2015. The statistical tool used is multiple linear regression. Result showed that partially inflation is not significant and have a negative relation toward ISSI's stock price, SBI interest rate is not significant and have a positive relation toward ISSI's stock price, exchange rate significantly influence the stock price at Indonesia Sharia Stock Index (ISSI) and have a negative effect. Simultaneously, both variable inflation rate, SBI interest rate and the exchange rate significantly influence the stock price's movement at Indonesia Sharia Stock Index (ISSI).

Keywords: ISSI, Indonesia Sharia Stock Index, inflation rate, SBI Interest rates, exchange rates of rupiah and multiple linear regression.
\end{abstract}

\section{PENDAHULUAN}

\section{Latar Belakang}

Kehadiran pasar modal di suatu negara dianggap sangat penting terkait perannya sebagai penggerak perekonomian nasional yang berfungsi menyediakan fasilitas untuk mempermudah perusahaan dan emiten mendapatkan dana serta bagi investor untuk menyalurkan dananya dengan harapan mendapat bagi hasil atas dana yang disalurkannya. Perkembangan saham syariah di pasar modal Indonesia diawali dengan diterbitkannya Jakarta Islamic Index (JII) pada Juli tahun 2000. Jakarta Islamic Index (JII) merupakan kelompok saham perusahaan go public yang terdaftar di Bursa Efek Indonesia (BEI) yang memenuhi kriteria syariah. Pada tanggal 12 Mei 2011, BEl menerbitkan Indonesia Sharia Stock Index (ISSI). ISSI berisikan seluruh saham syariah yang terdaftar di BEI.

Husnan (2009:16) dalam bukunya menjelaskan bahwa krisis finansial yang melanda Indonesia pada tahun 1997 mengakibatkan IHSG turun dari 635 menjadi 398 dan mulai bangkit kembali di tahun 2003. Pada tahun 2004, jumlah saham di BEJ berkurang cukup banyak karena banyak perusahaan yang melakukan reserve split. Nilai kapitalisasi

1) Jurnal ini merupakan bagian dari skripsi yang ditulis oleh Martien Rachmawati, 041114086 yang diuji pada 29 Juni 2015 
menurun karena harga-harga saham yang terdaftar di bursa mengalami penurunan. Di tahun 2002 kondisi perekonomian makro Indonesia mulai membaik dengan angka pertumbuhan ekonomi yang terus meningkat dan suku bunga yang terus menurun. Tingkat suku bunga Sertifikat Bank Indonesia (indikator tingkat keuntungan investasi bebas risiko) mencapai angka 7,4\% di akhir tahun 2004.

Krisis ekonomi global kembali terjadi pada tahun 2008 yang disebut sebagai krisis terparah sejak the great depression. Kebangkrutan salah satu perusahaan investment banking terbesar di Amerika Serikat yaitu Lehman Brothers menjadi penyebabnya. Nilai investasi terkuras tajam hampir rata-rata 40 persen. Negara ikon pertumbuhan ekonomi Asia seperti Cina, Jepang dan India tidak luput dari terpaan krisis. Indeks Harga Saham Gabungan (IHSG) terhempas hingga $50,35 \%$ dari 2731,35 ke level 1340,89 pada akhir tahun 2008. Minimnya jumlah emiten dan jumlah investor yang berinvestasi di pasar modal menyebabkan pasar modal Indonesia mudah terguncang jika terjadi gejolak eksternal. Jumlah emiten berkurang sebesar 2,9\% menjadi 396 perusahaan akibat mengalami delisting dari lantai bursa dan mengalami kerugian. Volatilitas yang tinggi terjadi pada rupiah yang terdepresiasi hingga $30,9 \%$ dari Rp 9.840 per Januari 2008 menjadi Rp 12.100 per November 2008 (www.ukrida.ac.id).

Perubahan yang terjadi pada faktor makroekonomi seperti inflasi, suku bunga dan nilai tukar mata uang akan direaksi oleh pasar modal sehingga faktor tersebut berpotensi untuk memengaruhi terbentuknya harga saham. Berkaca dari kejadian di masa lalu, indeks harga saham di pasar modal sangat rentan terhadap perubahan kondisi makro ekonomi baik dari dalam maupun luar negeri. Menurut Tandelilin (2010:341) fluktuasi yang terjadi di pasar modal akan terkait dengan perubahan yang terjadi pada berbagai variabel ekonomi makro. Perubahan yang terjadi pada faktor makroekonomi seperti inflasi, suku bunga dan nilai tukar mata vang akan direaksi oleh pasar modal sehingga faktor tersebut berpotensi untuk memengaruhi terbentuknya harga saham. Perubahan yang terjadi pada faktor makroekonomi merupakan salah satu bentuk risiko dalam melakukan investasi. Dari uraian di atas, maka peneliti ingin melakukan penelitian untuk mengetahui sejauh mana pergerakan indeks harga saham syariah dipengaruhi oleh perubahan-perubahan faktor makroekonomi.

\section{Perumusan Masalah}

a. Apakah ada pengaruh secara parsial dari perubahan suku bunga SBI, inflasi dan nilai tukar rupiah terhadap pergerakan harga saham pada Indeks Saham Syariah Indonesia di Bursa Efek Indonesia?

b. Apakah ada pengaruh secara simultan dari perubahan suku bunga SBI, inflasi dan nilai tukar rupiah terhadap pergerakan harga saham 
pada Indeks Saham Syariah Indonesia di Bursa Efek Indonesia?

\section{Tujuan Penelitian}

a. Mengetahui pengaruh secara parsial dari perubahan suku bunga SBI, inflasi dan nilai tukar rupiah terhadap pergerakan harga saham pada Indeks Saham Syariah Indonesia di Bursa Efek Indonesia.

b. Mengetahui pengaruh secara simultan dari perubahan suku bunga SBI, inflasi dan nilai tukar rupiah terhadap pergerakan harga saham pada Indeks Saham Syariah Indonesia di Bursa Efek Indonesia.

II. LANDASAN

TEORI

DAN

\section{PENGEMBANGAN HIPOTESIS}

\section{Pengertian Pasar Modal}

Pasar modal adalah pasar untuk memperjualbelikan sekuritas yang umumnya memiliki umur lebih dari satu tahun, seperti saham dan obligasi (Tandelilin, 2010:26).

\section{Inflasi}

Menurut Mishkin (2008:13) inflasi yaitu kenaikan tingkat harga yang terjadi secara terus-menerus, memengaruhi individu, pengusaha dan pemerintah. Fahmi (2006:83) menyatakan bahwa bagi kalangan investor sangat penting untuk menurunkan inflasi karena peningkatan inflasi secara relatif merupakan sinyal negatif bagi pemodal di pasar modal. Jika inflasi meningkat, pendapatan dan biaya perusahaan akan meningkat yaitu ketika peningkatan biaya produksi lebih tinggi daripada peningkatan harga yag dinikmati perusahaan maka profitabilitas perusahaan akan turun.

\section{Suku Bunga}

Suku bunga adalah biaya pinjaman atau harga yang dibayarkan untuk dana pinjaman. Suku bunga mempunyai dampak pada kesehatan perekonomian secara keseluruhan karena suku bunga tidak hanya dapat memengaruhi kesediaan konsumen untuk mengonsumsi atau menabung tapi juga memengaruhi keputusannya dalam berinvestasi (Mishkin, 2008:4).

Tandelilin (2010:243) menjelaskan bahwa tingkat bunga yang terlalu tinggi akan memengaruhi nilai sekarang aliran kas perusahaan sehingga kesempatan investasi yang ada tidak akan menarik lagi. Pada dasarnya untuk menentukan pendapatan bersih perusahaan akan dikurangi dengan beban bunga. Jika beban bunganya tinggi maka akan mengurangi laba bersih perusahaan sehingga akan memengaruhi harga sahamnya.

\section{Nilai Tukar}

Menurut Noor (2009:161) kurs adalah nilai tukar antar suatu mata uang dengan mata vang negara lain. Investor asing yang melakukan diversifikasi portofolio akan mengharapkan return atas investasinya dalam dua hal yaitu saham dan valas. Mereka juga menanggung risiko atas saham dan risiko nilai tukar. Laba yang diperoleh dari kepemilikan saham akan dikonversikan pada mata vang negara mereka, jika kurs mata vang 
negara asal investor tersebut menguat maka keuntungan yang didapat akan lebih kecil dibanding keuntungan yang didapat oleh investor domestik negara tempat ia menginvestasikan modal dan berlaku sebaliknya.

\section{Hubungan Antar Variabel}

Tandelilin (2010:343) mengatakan bahwa peningkatan inflasi secara relatif akan membawa sinyal negatif bagi pemodal di pasar modal. Inflasi meningkatkan pendapatan dan biaya perusahaan. Jika peningkatan biaya lebih tinggi dari peningkatan harga yang dapat dinikmati perusahaan, maka profitabilitas perusahaan akan menurun.

Inflasi yang tinggi menyebabkan harga bahan baku untuk poduksi perusahaan meningkat selain itu buruh juga menuntut kenaikan upah karena biaya hidup yang meningkat akibat harga kebutuhan bahan pokok naik. Hal ini tentu akan memengaruhi profitabilitas perusahaan karena beban biaya yang ditanggung semakin tinggi. Selain itu, inflasi menyebabkan konsumsi riil masyarakat berkurang karena nilai vang yang mereka pegang berkurang kemudian masyarakat akan mengurangi konsumsi mereka atas barang/jasa yang dihasilkan perusahaan otomatis pendapatan perusahaan ikut menurun dan memengaruhi keuntungan yang didapatnya selanjutnya berpengaruh pada harga saham perusahaan tersebut. Harga saham yang kian menurun akan memengaruhi niat investor untuk membeli saham perusahaan tersebut yang pada akhirnya juga berpengaruh pada indeks harga saham. Penelitian yang mendukung hipotesis mengenai variabel inflasi mempunyai pengaruh negatif terhadap indeks harga saham adalah penelitian yang dilakukan oleh Rusbariandi dkk (2012) dan Rizky dan Yousuf (2013).

Pada perusahaan yang struktur modalnya banyak menggunakan pinjaman yang berbasis bunga, kenaikan pada suku bunga pinjaman yang tinggi menyebabkan beban bunga kredit meningkat dan laba bersih menurun. Laba bersih perusahaan yang mengalami penurunan akan diikuti laba per saham turun dan selanjutnya berdampak pada harga saham yang melemah. Bukti empiris yang menunjukkan bahwa suku bunga memiliki pengaruh negatif pada indeks harga saham didapatkan dari penelitian Wicaksono (2010), Vejzagic dan Hashem (2013), Antonio dkk (2013) dan Lailia dkk (2014).

Mishkin (2008:231) menyebutkan bahwa permintaan surat berharga dipengaruhi oleh suku bunga, kekayaan, tingkat inflasi dan kurs. Kenaikan kurs mata vang akan membawa dampak yang berbeda pada setiap perusahaan. Bagi perusahaan yang memiliki hutang dalam bentuk dolar, kenaikan dolar akan sangat dirasakan dampaknya karena beban perusahaan untuk membayar hutang menjadi lebih tinggi. Bagi perusahaan yang kegiatan utamanya pada aktivitas ekspor maka akan mendapat dampak 
positif dari kenaikan kurs dolar (rupiah menguat), sedangkan pada perusahaan yang mendapat dampak negatif akan berpengaruh pada penurunan harga saham. Perubahan pada kurs juga akan memengaruhi pembentukan harga barang atau jasa impor-ekspor sehingga hal tersebut akan berpengaruh langsung pada profitabilitas perusahaan. Hasil penelitian terdahulu yang menunjukkan bahwa nilai tukar rupiah terhadap dolar Amerika berpengaruh negatif dilakukan oleh Wicaksono (2010), Rusbariandi dkk (2012), Vejzagic dan Hashem (2013) dan Lailia dkk (2014).

$\mathrm{HI}$ : variabel inflasi berpengaruh secara negatif dan signifikan terhadap pergerakan harga saham pada Indeks Saham Syariah Indonesia di BEI.

H2 : variabel suku bunga SBI berpengaruh secara negatif dan signifikan terhadap pergerakan harga saham pada Indeks Saham Syariah Indonesia di BEl.

H3 : variabel nilai tukar mata vang asing berpengaruh secara negatif dan signifikan terhadap pergerakan harga saham pada Indeks Saham Syariah Indonesia di BEI.

H4 : variabel inflasi, suku bunga SBI dan nilai tukar rupiah secara simultan berpengaruh secara negatif terhadap pergerakan harga saham pada Indeks Saham Syariah Indonesia di BEI.

\section{Model Analisis}

Model analisis dalam penelitian ini dipaparkan dalam bagan berikut:

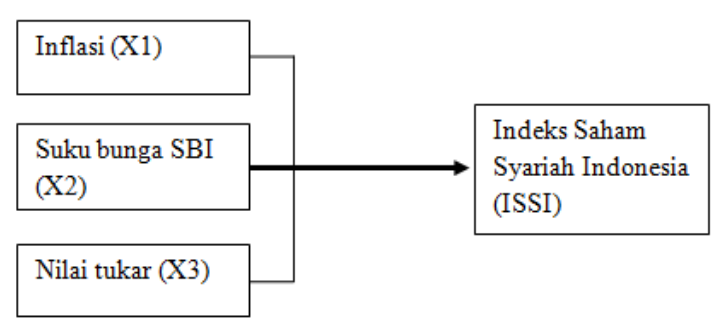

Gambar 1.

Model Analisis

\section{METODE PENELITIAN}

\section{Pendekatan Penelitian}

Pendekatan yang digunakan dalam penelitian ini adalah pendekatan kuantitatif.

Uji statistik yang digunakan dalam analisis adalah metode regresi linear berganda, asumsi klasik, koefisiensi determinasi, uji $F$ dan uji t. Data diperoleh dari laporan bulanan Bank Indonesia dan Bursa Efek Indonesia periode Januari 2012 hingga April 2015 sehingga jumlah observasi adalah 40 .

\section{Identifikasi Variabel}

Variabel independen yang digunakan dalam penelitian ini adalah:

1. Inflasi

2. Suku bunga $S B I$

3. Nilai Tukar rupiah

Variabel dependennya adalah Indeks Saham Syariah Indonesia (ISSI).

\section{Definisi Operasional}

Definisi Operasional dari variabelvariabel adalah sebagai berikut:

1. Inflasi = (IHK pada bulan $\mathrm{n}-\mathbf{I H K}$ pada bulan $n-1)$ : IHK pada bulan $\mathrm{n}-1 \times 100$ 
Sumber data dari Bank Indonesia dengan skala pengukuran prosentase serta jenis data bulanan.

2. Suku Bunga $S B I=$ jumlah suku bunga perode harian selama 1 bulan : jumlah periode waktu 1 bulan

Data didapatkan dari Bank Indonesia, jenis data bulanan dengan skala prosentase.

3. Nilai Tukar

Kurs tengah $=($ kurs jual+kurs beli) : 2

Data didapatkan dari Bank Indonesia dengan jenis data bulanan dalam skala rupiah.

4. $\mathbf{I S S I}=$ (Total seluruh harga saham pada waktu berlaku : total harga semua saham pada waktu dasar) X $100 \%$

Data Indek Saham Syariah Indonesia didapatkan dari Laporan Ringkasan Indeks Bursa Efek Indonesia dengan jenis data bulanan dan skala prosentase.

\section{Uji Asumsi Klasik}

a. Autokorelasi, digunakan untuk mengetahui adanya hubungan kesalahan pengamatan (error residual). Untuk mengidentifikasi gejala autokorelasi dilakukan dengan uji Durbin-Watson. Jika nilai uji Durbin-Watson berada di antara nilai dU dan 4-dU, maka dapat disimpulkan bahwa tidak terjadi autokolerasi (Sarjono, $2011: 84)$.

b. Multikolinieritas, asumsi yang menunjukkan adanya hubungan linear yang kuat diantara beberapa variabel prediktor dalam suatu model regresi linear berganda. Model regresi yang baik tidak ditemukan multikolinier atau korelasi di antara variabel bebas (Santoso, 1999: 283). Untuk mengetahui ada tidaknya gejala multikolinieritas dapat dilihat dari nilai VIF (Variance-inflating factor) dan nilai tolerance. Jika nilai VIF lebih dari 10 dan nilai toleransinya kurang dari 0,1 , maka dapat disimpulkan terjadi multikolinieritas.

c. Heteroskedastisitas, untuk melihat dari model regresi yang memiliki varian tidak konstan. Uji yang digunakan untuk mengetahui ada tidaknya gejala heteroskedastisitas yaitu dengan scatterplot. Cara menganalisis terjadinya gejala heteroskedastisitas dengan melihat pola titik-titik teratur seperti gelombang yang melebar kemudian menyempit. Jika hal tersebut terjadi maka menandakan adanya gejala heteroskedastisitas.

d. Normalitas, digunakan untuk melihat model regresi variabel independen dan dependen telah memenuhi syarat distribusi normal. Cara mencari tahu apakah data 
berdistribusi normal dengan melihat grafik P-P plot.

\section{Uji Regresi Linear Berganda}

Analisis regresi linear berganda digunakan untuk menguji pengaruh antara tingkat inflasi, suku bunga SBI dan nilai tukar rupiah terhadap ISSI. Untuk mengetahui seberapa berpengaruh variabel independen terhadap variabel dependen digunakan persamaan regresi sebagai berikut:

$Y=a+\beta 1 \times 1+\beta 2 X 2+\beta 3 \times 3+e$

Keterangan:

$$
\begin{aligned}
& Y=|S S| \\
& a=\text { konstanta } \\
& \beta=\text { koefisien garis regresi } \\
& X 1=\text { tingkat inflasi } \\
& X 2=\text { suku bunga } S B \mid \\
& X 3=\text { nilai tukar/kurs rupiah } \\
& \quad \text { terhadap dolar Amerika } \\
& \text { e = standard error }
\end{aligned}
$$

\section{Uji Goodness of Fit}

Menurut Wicaksono (2010: 83) untuk mengukur ketepatan fungsi regresi dalam menaksir nilai aktual dapat dilihat dari Goodness of Fit, menggunakan metode statistik sebagai berikut:

a. Koefisien Determinasi

digunakan untuk mengetahui seberapa besar model dapat menjelaskan variabel dependen.

b. Uji $F$ digunakan untuk melihat signifikansi hasil dari model regresi secara bersama-sama (simultan).

c. Uji t digunakan untuk membuktikan hipotesis bahwa ada pengaruh variabel independen terhadap variabel dependen secara parsial.

\section{HASIL PENELITIAN DAN PEMBAHASAN}

\begin{tabular}{|c|c|c|c|}
\hline $\begin{array}{l}\text { Nilai Durbin- } \\
\text { Watsoon }\end{array}$ & Niliai DU dan DL & $\begin{array}{c}\text { Inteppetasis } \\
\text { Hasil }\end{array}$ & Keterangan \\
\hline 1,767 & $\begin{array}{l}\mathrm{DU}=1,6589 ; \\
\mathrm{DL}=1,3384\end{array}$ & $D W>D U$ & $\begin{array}{l}\text { Tidak terjadi } \\
\text { Autokoleterasi }\end{array}$ \\
\hline
\end{tabular}

Dari hasil pengujian menunjukkan bahwa variabel yang digunakan telah lolos uji asumsi klasik. Hasil pengujian menggunakan SPSS 16 ditunjukkan pada tabel berikut.

Tabel 1.

Uji Autokorelasi

Sumber: hasil uji SPSS 16 (data telah diolah)

Berdasarkan pada tabel di atas, diperoleh nilai Durbin-Watson 1,767 yang lebih besar dari nilai dU; dan nilai $4-\mathrm{dU}=2,233$ sehingga $1,6589<1,767$ $<2,233$. Dapat disimpulkan bahwa penelitian ini telah terbebas dari autokolerasi dan variabel-variabel independen yang ada dapat digunakan untuk menjelaskan variabel dependen.

Tabel 2.

Uji Multikolinieritas

\begin{tabular}{|c|c|c|c|c|}
\hline $\begin{array}{c}\text { Variabel } \\
\text { Bebas }\end{array}$ & $\begin{array}{c}\text { Nilai } \\
\text { VIF }\end{array}$ & $\begin{array}{c}\text { Nilai } \\
\text { Tolerance }\end{array}$ & Interpretasi Hasil & Keterangan \\
\hline Inflasi & 1,062 & 0,941 & $\begin{array}{c}\text { Nilai toleransi }>0,10 ; \\
\text { Nilai VIF }<10\end{array}$ & $\begin{array}{c}\text { Tidak Terjadi } \\
\text { Multikolinieritas }\end{array}$ \\
\hline $\begin{array}{c}\text { Suku bunga } \\
\text { SBI }\end{array}$ & 1,124 & 0,890 & $\begin{array}{c}\text { Nilai toleransi }>0,10 ; \\
\text { Nilai VIF }<10\end{array}$ & $\begin{array}{c}\text { Tidak Terjadi } \\
\text { Multikolinieritas }\end{array}$ \\
\hline $\begin{array}{c}\text { Nilai tukar } \\
\text { rupiah }\end{array}$ & 1,175 & 0,851 & $\begin{array}{c}\text { Nilai toleransi }>0,10 ; \\
\text { Nilai VIF }<10\end{array}$ & $\begin{array}{c}\text { Tidak Terjadi } \\
\text { Multikolinieritas }\end{array}$ \\
\hline
\end{tabular}

Sumber: hasil uji SPSS 16 (data telah diolah) 
Dari hasil pengujian yang telah disajikan pada tabel di atas, didapatkan nilai toleransi dari masingmasing variabel bebas jauh lebih besar dari 0,10 dengan nilai VIF kurang dari 10. Kesimpulannya adalah tidak terjadi multikolinieritas pada model penelitian ini.

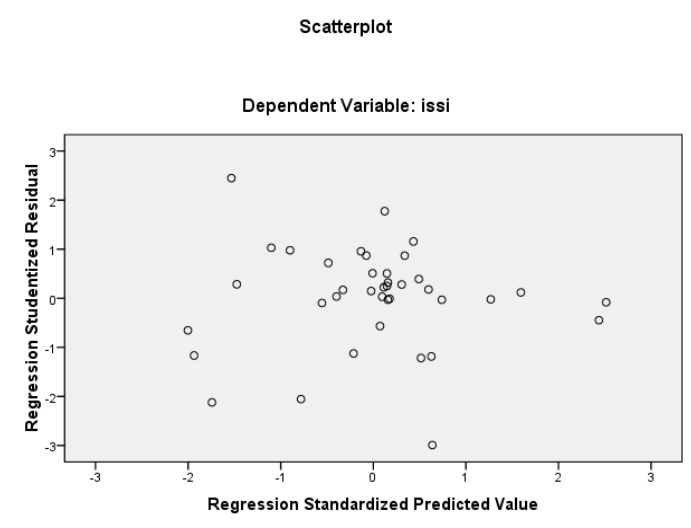

Gambar 2.

Uji Heteroskedastisitas

Berdasarkan scatterplot di atas, dapat dilihat bahwa titik-titik menyebar baik di atas maupun di bawah angka nol dari sumbu $Y$, sehingga dapat diambil kesimpulan bahwa tidak terjadi heteroskedastisitas pada model penelitian.

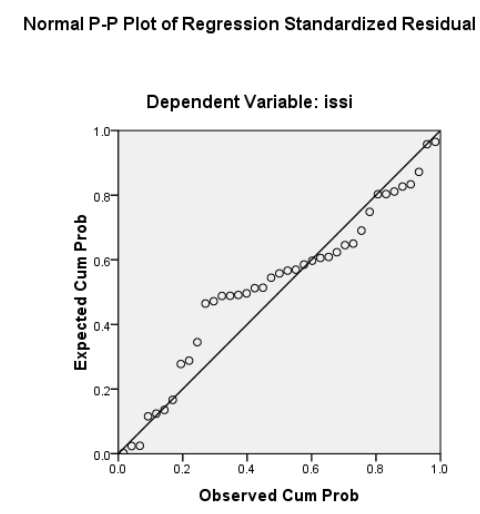

Gambar 3.

Uji Normalitas
Tabel 3.

Hasil Uji Regresi Linear Berganda

\begin{tabular}{|c|c|c|}
\hline Variabel & Koefisien Regresi & Keterangan \\
\hline Konstanta & 1,846 & Konstanta \\
\hline Inflasi & $-1,334$ & Benilai negatif \\
\hline Suku bunga SBI & 0,365 & Bernilai positif \\
\hline Nilai tukar rupiah & $-0,010$ & Bernilai negatif \\
\hline
\end{tabular}

Sumber: hasil uji SPSS 16 (data telah diolah)

Dari hasil uji regresi tersebut didapatkan persamaan regresi:

$Y=1,846-1,334$ Inflasi $+0,365$ SBI -

0,010 Kurs

Dari persamaan tersebut dapat dijelaskan bahwa:

1. Konstanta sebesar 1,846 dapat diartikan bahwa jika tidak ada tingkat inflasi, suku bunga SBI dan nilai tukar rupiah atau nilai variabel bebasnya adalah nol atau konstan maka perubahan ISSI adalah 1,846 satuan.

2. Koefisien regresi $X 1$ adalah $-1,334$ menandakan bahwa setiap pengurangan tingkat inflasi (karena tanda -) 1 satuan maka dapat meningkatkan ISSI sebesar 1,334. Begitu pula sebaliknya, jika terjadi penambahan tingkat inflasi sebesar 1 satuan maka dapat menurunkan ISSI sebesar 1,334 dengan asumsi nilai variabel lain adalah konstan atau nol.

3. Koefisien regresi $X 2$ adalah 0,365 menandakan bahwa setiap penambahan suku bunga SBI 1 satuan maka dapat meningkatkan ISSI sebesar 0,365. Ini berlaku 
sebaliknya, jika terjadi
pengurangan pada suku bunga
SBI sebesar I satuan maka akan
menurunkan ISSI sebesar 0,365
dengan asumsi variabel lain
bernilai konstan atau nol

4. Koefisien regresi $X 3$ adalah $-0,010$ menandakan bahwa setiap pengurangan nilai tukar rupiah 1 satuan dapat meningkatkan ISSI sebesar 0,010 satuan. Hal ini dapat berlaku sebaliknya, jika terjadi penambahan pada nilai tukar rupiah sebesar 1 satuan akan menyebabkan menurunnya ISSI sebesar 0,010 dengan asumsi variabel lain bernilai konstan atau nol.

Koefisien determinasi $\left(R^{2}\right)$ digunakan untuk mengukur kemampuan model dalam menjelaskan variabel terikat. Nilai koefisien determinasi yang kecil menunjukkan keterbatasan kemampuan variabel bebas dalam menerangkan variabel terikat. Nilai $R^{2}$ yang digunakan dalam perhitungan statistik penelitian ini adalah adjusted $R$ square dimana nilai ini merupakan suatu indikator untuk mengetahui pengaruh penambahan suatu variabel bebas ke dalam persamaan regresi. Nilai adjusted $\mathrm{R}^{2}$ telah dibebaskan dari pengaruh derajat kebebasan yang artinya nilai tersebut telah benar-benar menunjukkan bagaimana pengaruh variabel independen terhadap variabel dependen.
Hasil dari adjusted $R$ square sebesar 0,202 atau $20,2 \%$. Angka tersebut menunjukkan bahwa variabel independen yaitu inflasi, suku bunga SBI dan nilai tukar rupiah dapat menjelaskan variabel dependen ISSI sebesar 20,2\%, sementara sisanya sebesar $79,8 \%$ dipengaruhi oleh faktor lain yang tidak dimasukkan dalam model penelitian.

\section{Pengujian Hipotesis}

\section{Uji F}

Uji ini digunakan untuk mencari tahu pengaruh secara simultan atau bersamasama dari variabel independen terhadap variabel dependen. Uji simultan dalam penelitian ini menggunakan hipotesis sebagai berikut:

Ho : Variabel tingkat inflasi, suku bunga SBI dan nilai tukar rupiah diduga tidak signifikan berpengaruh terhadap pergerakan harga saham pada Indeks Saham Syariah Indonesia.

Ha: Variabel tingkat inflasi, suku bunga SBI dan nilai tukar rupiah secara simultan diduga signifikan berpengaruh terhadap pergerakan harga saham pada Indeks Saham Syariah Indonesia. 
Tabel 4.

Hasil Uji F

\begin{tabular}{|c|c|l|l|}
\hline $\begin{array}{c}\mathrm{F} \\
\text { Hitung }\end{array}$ & $\begin{array}{c}\mathrm{F} \\
\text { Tabel }\end{array}$ & \multicolumn{1}{|c|}{ Interpretasi } & \multicolumn{1}{c|}{ Keterangan } \\
\hline 4,201 & 2,86 & $\begin{array}{l}\text { F hitung }>\mathrm{F} \text { tabel } \\
\text { atau 4,201 }>2,86, \\
\text { Ho ditolak } \\
\text { Signifikansi }<0,05\end{array}$ & $\begin{array}{l}\text { Ho ditolak. Kesimpulannya } \\
\text { secara simultan variabel independen } \\
\text { berpenganuh secara signifikan terhadap } \\
\text { variabel dependen. }\end{array}$ \\
\hline & $\begin{array}{l}\text { ataul 0,012, Ho } \\
\text { ditolak }\end{array}$ & \\
\hline
\end{tabular}

Sumber: hasil uji SPSS 16 (data telah diolah)

Dari tabel hasil uji $F$ di atas, menunjukkan bahwa pengaruh tingkat inflasi, suku bunga SBI dan nilai tukar rupiah terhadap pergerakan harga saham pada Indeks Saham Syariah Indonesia (ISSI) adalah sebesar 4,201 dengan signifikansi 0,012 . Nilai signifikansi yang lebih kecil dari 0,05 menandakan bahwa variabel independen tingkat inflasi, suku bunga $\mathrm{SBI}$ dan nilai tukar rupiah secara simultan atau bersama-sama berpengaruh secara signifikan terhadap pergerakan harga saham ISSI.

\section{Uji $\uparrow$}

Uji ini digunakan untuk menguji pengaruh variabel bebas terhadap variabel terikat secara sendiri-sendiri atau parsial. Dasar dalam pengambilan keputusan menggunakan tingkat signifikansi 5\%, dimana jika signifikansi variabel independen kurang dari 0,05 dan nilai $\dagger$ hitung > † tabel, maka Ho ditolak. Uji parsial dalam penelitian ini menggunakan hipotesis berikut:

Ho: Variabel tingkat inflasi, suku bunga SBI dan nilai tukar rupiah secara parsial diduga tidak berpengaruh secara signifikan

terhadap

pergerakan Indeks Saham

Syariah Indonesia.

$\mathrm{Hb}$ : Variabel tingkat inflasi, suku bunga $\mathrm{SBI}$ dan nilai tukar rupiah secara parsial diduga berpengaruh secara signifikan terhadap pergerakan Indeks Saham Syariah Indonesia

Tabel 5.

Hasil Uji $\dagger$

\begin{tabular}{|c|c|c|c|c|c|}
\hline $\begin{array}{c}\text { Variabel } \\
\text { Independen }\end{array}$ & $\begin{array}{c}\mathrm{t} \\
\text { hitung }\end{array}$ & $\begin{array}{c}\mathrm{t} \\
\text { tabel }\end{array}$ & Sig & Interpretasi Hasil & Keterangan \\
\hline Inflasi & 1,229 & 2,026 & 0,227 & $\begin{array}{c}\text { thitung }<\mathrm{t} \text { tabel, } \\
\text { Sig }>0,05\end{array}$ & Tidak Signifikan \\
\hline $\begin{array}{c}\text { Suku bunga } \\
\text { SBI }\end{array}$ & 0,116 & 2,026 & 0,908 & $\begin{array}{c}\mathrm{t} \text { hitung }<\mathrm{t} \text { tabel, } \\
\text { Sig }>0,05\end{array}$ & Tidak Signifikan \\
\hline $\begin{array}{c}\text { Nilai tukar } \\
\text { rupiah }\end{array}$ & 2,831 & 2,026 & 0,008 & $\begin{array}{c}\mathrm{t} \text { hitung }>\mathrm{t} \text { tabel, } \\
\text { Sig }<0,05\end{array}$ & Signifikan \\
\hline
\end{tabular}

Sumber: hasil uji SPSS 16 (data telah diolah)

Hasil pengujian secara parsial di atas menunjukkan bahwa tingkat inflasi memiliki signifikansi sebesar 0,227, suku bunga SBI 0,908 dan nilai tukar rupiah 0,008 . Nilai signifikansi variabel independen yang lebih kecil dari $a=5 \%$ dan nilai $†$ hitung $>$ † tabel hanya dimiliki oleh nilai tukar rupiah. Sehingga dapat disimpulkan bahwa secara parsial hanya nilai tukar rupiah yang mempunyai pengaruh secara signifikan terhadap pergerakan harga saham pada Indeks Saham Syariah Indonesia.

Inflasi merupakan salah satu variabel makroekonomi yang paling penting dan memiliki pengaruh besar baik pada sektor riil maupun sektor keuangan. Tingkat inflasi pada penelitian ini berpengaruh tidak 
signifikan dengan nilai negatif sebesar 1,334 yang menunjukkan bahwa inflasi dan Indeks Saham Syariah Indonesia memiliki hubungan yang tidak searah atau berlawanan dimana ketika tingkat inflasi naik maka ISSI akan mengalami penurunan. Tandelilin (2010:343) mengatakan bahwa peningkatan inflasi secara relatif akan membawa sinyal negatif bagi pemodal di pasar modal. Kenaikan inflasi menyebabkan konsumsi riil masyarakat berkurang karena nilai vang yang dipegang masyarakat menjadi turun. Akibat naiknya harga barang dan jasa maka masyarakat lebih memilih untuk menahan kebutuhan konsumsi mereka atau setidaknya menghemat pengeluaran. Dengan pengurangan konsumsi oleh masyarakat maka penjualan perusahaan otomatis akan berkurang sehingga keuntungan yang mereka dapatkan pun turut berkurang.

Inflasi juga dapat mendorong buruh untuk menaikkan gajinya karena harga kebutuhan hidup mereka yang meningkat seiring harga kebutuhan pokok yang meningkat begitu pula harga bahan baku yang digunakan perusahaan pasti juga meningkat. Oleh karena itu, inflasi yang tinggi akan menyebabkan tingginya beban biaya perusahaan. Beban biaya operasional yang tinggi dapat mengurangi tingkat profitabilitas yang dinikmati perusahaan. Kemampuan perusahaan untuk menghasilkan keuntungan akan memengaruhi laba per saham. Investor cenderung akan tertarik dengan investasi yang memberikan tingkat keuntungan yang sesuai dengan tingkat risiko yang dapat ia tanggung. Jika keuntungan yang didapat lebih kecil dari risiko yang harus ditanggung maka mereka akan menjual sebagian atau seluruh sahamnya. Aksi jual saham besarbesaran yang dilakukan oleh investor akan memengaruhi nilai indeks harga saham.

Hasil uji hipotesis secara parsial terhadap variabel tingkat inflasi menunjukkan bahwa inflasi berpengaruh tidak signifikan terhadap Indeks Saham Syariah Indonesia. Ini dapat diartikan bahwa selama periode pengamatan tingkat inflasi tidak memengaruhi keputusan investor untuk berinvestasi dalam bentuk saham secara langsung. Investor tidak menggunakan tingkat inflasi sebagai tolok ukur atau bahan pertimbangan dalam membuat sebuah keputusan untuk melakukan investasi. Investor melakukan pengamatan pada faktor lain yang dapat memengaruhi saham seperti suku bunga SBI dan nilai tukar rupiah terhadap dolar Amerika secara bersama-sama kemudian baru menentukan keputusan investasinya.

Triani dan Etty (2013) mengutip dari penelitian Lee (1992) yang menemukan bahwa perubahan pada suku bunga memberikan pengaruh signifikan pada indeks harga saham. Hal ini didukung dengan teori yang dijelaskan oleh Tandelilin (2010:343) yang menjelaskan bahwa suku bunga yang tinggi 
merupakan sinyal negatif pada harga saham dimana investor akan cenderung tertarik berinvestasi dan memindahkan investasinya dalam bentuk tabungan atau deposito. Dari teori dan hasil penelitian terdahulu yang digunakan sebagai literatur dalam penelitian ini, sebagian besar banyak yang menemukan bahwa suku bunga berpengaruh negatif pada pasar modal. Namun hasil dalam penelitian ini justru menemukan hal yang bertentangan dengan teori dan penelitian sebelumnya bahwa tingkat suku bunga mempunyai pengaruh yang positif terhadap indeks harga saham di pasar modal. Penelitian terdahulu yang mendukung hasil dari penelitian ini adalah penelitian yang dilakukan oleh Amin (2012) yang menyimpulan bahwa suku bunga berpengaruh positif terhadap indeks harga saham. Mishkin dalam teori portofolio (2008:231) menjelaskan bahwa permintaan surat berharga dipengaruhi oleh suku bunga, kekayaan, tingkat inflasi dan kurs. Tetapi pada hasil uji hipotesis, menunjukkan bahwa variabel suku bunga SBI berpengaruh tidak signifikan terhadap Indeks Saham Syariah Indonesia. Selama periode pengamatan, investor menggunakan faktor lain seperti tingkat inflasi, kurs tukar rupiah dan lainnya secara bersama-sama dalam membuat sebuah keputusan berinvestasi pada saham di Bursa Efek Indonesia. Selain itu, yang paling penting adalah saham-saham yang tergabung dalam Indeks Saham Syariah Indonesia telah melalui proses screening dimana usaha yang dilakukan perusahaan tidak berkonsep ribawi; hutang berbasis bunga dibatasi yaitu tidak boleh lebih dari 45\%; pendapatan bunga tidak boleh lebih dari $10 \%$. Hal ini menjadi salah satu keunggulan produk syariah dimana perubahan pada suku bunga tidak akan membawa dampak yang sangat berarti pada indeks saham syariah.

Teori portofolio Mishkin (2008:231) menyebutkan bahwa permintaan surat berharga dipengaruhi oleh suku bunga, kekayaan, tingkat inflasi dan kurs. Hasil uji hipotesis dalam penelitian ini menemukan bahwa variabel nilai tukar rupiah mempunyai pengaruh signifikan terhadap pergerakan Indeks Saham Syariah Indonesia. Hasil penelitian ini sejalan dengan hasil penelitian terdahulu yang dilakukan oleh Rusbariandi dkk (2012), Wicaksono (2010), Vezjavig dan Hashem (2013) dan Lailia dkk (2014). Hasil penelitian tersebut sesuai dengan teori yang ada. Hal ini menandakan bahwa investor menggunakan faktor nilai tukar rupiah sebagai tolok ukur untuk membuat sebuah keputusan berinvestasi pada saham di BEl secara parsial.

Grafik Perubahan ISSI

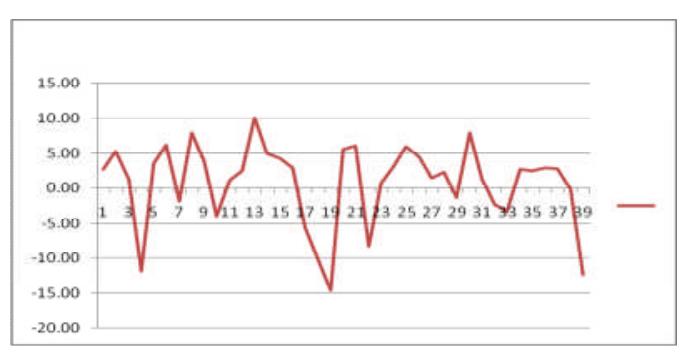

Grafik Perubahan Nilai Tukar 


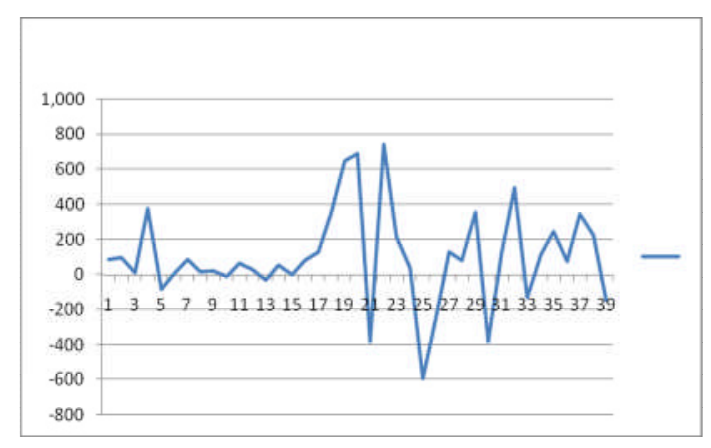

Dari grafik di atas terlihat bahwa ketika nilai tukar berubah naik maka ISSI akan turun. Begitu pula sebaliknya, ketika nilai tukar turun maka ISSI akan naik. Hal ini menunjukkan bahwa nilai tukar dan pergerakan harga saham pada ISSI memiliki hubungan negatif secara signifikan.

\section{SIMPULAN}

Berdasarkan pada hasil analisis dan pembahasan di bab sebelumnya, maka kesimpulan yang dapat diambil adalah sebagai berikut:

1. Tingkat inflasi secara parsial berpengaruh secara tidak signifikan terhadap pergerakan harga saham pada Indeks Saham Syariah Indonesia (ISSI).

2. Suku bunga $\mathrm{SBI}$ secara parsial berpengaruh secara tidak signifikan terhadap pergerakan harga saham Indeks Saham Syariah Indonesia (ISSI).

3. Nilai tukar rupiah secara parsial berpengaruh secara signifikan negatif terhadap Indeks Saham Syariah Indonesia (ISSI).

4. Secara simultan, tingkat inflasi, suku bunga SBI dan nilai tukar rupiah berpengaruh secara signifikan

$$
\begin{aligned}
& \text { terhadap Indeks Saham Syariah } \\
& \text { Indonesia (ISSI) dengan } \\
& \text { persamaan regresi berikut: } \\
& \text { ISSI }=1,846-1,334 \text { (Inflasi) }+0,365 \\
& \text { (SBI) }-0,010 \text { (Kurs) }
\end{aligned}
$$

\section{DAFTAR PUSTAKA}

Alfina. 2012. Pengaruh Variabel Makroekonomi Terhadap Indeks Saham Gabungan (IHSG) dan JII. Skripsi tidak diterbitkan Universitas Airlangga

Amin, M. Zuhdi. 2012. Pengaruh Tingkat Inflasi, Suku Bunga SBI, Nilai Kurs Dollar (USD/IDR) dan Indeks Dow Jones (DJIA) Terhadap Pergerakan Indeks Harga Saham Gabungan di Bursa Efek Indonesia (BEI) (Periode 2008-2011). Jurnal Skripsi Universitas Brawijaya

Antonio, Muhammad Syafii dkk. 2013. The Islamic Capital Market Volatility: A Comparative Study Between in Indonesia and Malaysia. Bulletin of Monetary, Economics and Banking, April

(http://www.bi.go.id/en/publikasi/jurnal -ekonomi html diakses November 27, 2014, 4:03:54 PM)

Bank Indonesia. 2015. Lelang Sertifikat BI, Januari 2012-April 2015. (Online), (http://www.bi.go.id/id/moneter/lelang -sbi/default.aspx, diakses tanggal 17 November 2014)

Bank Indonesia. 2015. Data Inflasi. Januari 2012-April 2015. (Online), (http://www.bi.go.id/id/moneter/inflasi/ 
data/Default.aspx, diakses tanggal 17 November 2014)

Bursa Efek Indonesia. 2014. Ringkasan Indeks di BEI, Januari 2012-April 2015. (Online), (http://www.idx.co.id/idid/beranda/unduhdata/ringkasan.aspx, diakses tanggal 17 November 2014)

Fahmi, Irham. 2006. Analisis Investasi dalam Perspektif Ekonomi dan Politik. Bandung: PT Refika Aditama

Husnan, Suad. 2009. Dasar-dasar Teori Portofolio \& Analisis Sekuritas, Edisi Keempat. Yogyakarta: Sekolah Tinggi IImU Manajemen YKPN

Mishkin, Frederic. 2008. Ekonomi Uang, Perbankan dan Pasar Keuangan, Edisi 8. Jakarta: Salemba Empat

Noor, Henry Faizal. 2009. Investasi, Pengelolaan Keuangan Bisnis dan Pengembangan Ekonomi Masyarakat. Jakarta: PT Indeks

Rusbariandi, Septian Prima dkk. 2012. Analisis Pengaruh Tingkat Inflasi, Harga Minyak Dunia, Harga Emas Dunia dan Kurs Rupiah Terhadap Pergerakan Jakarta Islamic Index di Bursa Efek Indonesia. Prosiding Seminar Nasional Forum Bisnis \& Keuangan I hal.724-740, Th. 2012 ISBN:978-602-17225-0-3 diakses November 12, 2014, 1:10:33 PM)

Sakti, Muhammad Rizky Prima dan MD.Yousuf Harun. 2013. Relationship between Stock Prices and Macroeconomic Variabel: Evidence from Jakarta Stock Exchange Islamic Index. Global Review of Islamic and Business, Vol.1 No.I (2013) 071-084 ISSN
2338-7920 (Online) (febi.uin-suka.ac.id diakses November 27, 2014, 5:1 1:06 PM) Santoso, Singgih. 1999. SPSS, Mengelola Data Statistik Secara Profesional Versi 7.5. Jakarta: PT Gramedia

Sarjono, Haryadi dan Winda Julianita. 2011. SPSS VS LISREL, Sebuah Pengantar, Aplikasi untuk Riset. Jakarta: Salemba Empat.

Tandelilin, Eduardus. 2010. Portofolio dan Investasi Teori dan Aplikasi, Edisi Pertama. Yogyakarta: Kanisius

Triani, Lely Fera dan Etty Puji Lestari. 2013. Comparison of Factors Toward the Changes of Composite Stock Price Index in LQ45 and Jakarta Islamic Index (Case Study in Indonesian Stock Exchange). IPEDR (International Proceedings of Economics Development and Research) Vol.65.15 hal.72-76, 2013 (Online) (www.ipedr.com/vol65lCEBI.html diakses November 26, 2014 2:53:38 PM) Vejzagic, Mirza dan Hashem Zarafat. 2013. Relationship Between Macroeconomic Variables and Stock Market Index: CoIntegration Evidence From FTSE Bursa Malaysia Hijrah Shariah Index. Asian Journal of Management Science and Education, Vol.2 No.4 hal.94-108, October 2013 ISSN:2186-845X (Online) (http://www.ajmse.leena-

luna.co.jp/html diakses November 27, 2014, 12:23:40 AM)

Wicaksono, Ardian Agung. 2010. Analisis Pengaruh Tingkat Suku Bunga SBI, Harga Minyak Dunia, Harga Emas 
Dunia, Kurs Rupiah, Indeks Nikkei 225, dan Indeks Dow Jones terhadap IHSG (studi kasus pada IHSG di BEI selama periode 2000-2009). Tesis tidak diterbitkan Program Pascasarjana Universitas Diponegoro diakses 9 November 2014, 4:39:17 PM

Wijaya, Hendri. 2015. Analisa Pasar Finansial Indonesia Hadapi Krisis Hutang Eropa,

(http://www.ukrida.ac.id/idxcorner/ind ex.php/14-sample-data-articles/77analisa-pasar-finansial diakses 16 April 2015) 